\title{
Stress on the Tenure Track: A Narrative of my Induction Year as an Education Professor
}

\section{Darlene Ciuffetelli Parker}

\section{I miss my father.}

He died this past February, while I was in the midst of my induction year as an assistant professor in the Faculty of Education Pre-service Department at Brock University. It was a difficult time, as anyone who has experienced loss would know, to continue living, doing, working alongside the painful sting of grief. Just a few months ago, another tragedy: the death of a student I had worked closely with in one of my foundational methods courses.

\section{Students, faculty and family grieve for Caitlin.}

You might predict that the stress and anxiety of grief, coupled with the inevitable stress and anxiety of life as a new pretenure member, would place anyone's experiences at the margins of darkness, isolation and even abandonment of teaching and scholarly work altogether. Instead, I am left to share a most challenging time not with words of despair, but with a story that I believe offers hope in light of disheartenment. The ability to deal with the stress and anxiety in my induction year has offered me insights into the characteristics of an authentic learning faculty and what it means to live life both personally and professionally in community with other learners.

Before I continue the story, I want to qualify that this is my personal narrative of my per- sonal professional knowledge (Connelly \& Clandinin, 1999, 1987; Clandinin \& Connelly, 2000) experiences of my induction year. Other colleagues and contemporaries, I know to be true, also have interpretive and profound stories of their own induction year at Brock University. My intention here is to examine the positive aspects, the encouraging lessons learned, of what has taken me through, up, and over the stresses and anxieties of my critical first year and to envisage further possibility; in other words, what can we learn about what it means to "go through" induction? After all, just as those of us as new faculty have gone through our own induction experiences, so too will the very education candidates we teach when they are awarded their first teaching assignment. The affective domain (Krathwohl et al., 1964) of receiving, responding, valuing, organizing and internalizing the conditions of which we experience, I believe, speak to the matter of how we live, work and "become" with others during a critical time, such as induction.

During my induction year, I kept journals and letters of my experiences as a new assistant professor. Letters to colleagues and personal reflective journals were written at least once per month beginning in August 2005; they continue today. I use these writings, in this article, as "data" in order to explore the conditions and characteristics of the faculty that I believe have taken me "through, up and over", represented under the following headings: a) living in community at the teaching learning faculty; b) understanding ourselves as learners and educators through critical incidences; c) writing and teaching: what brings us back to Joy; and, d) the ethics of care

\section{a) Living in community at} the teaching learning faculty

I feel very fortunate, all around, at the collegiality that so many have shown as I get started. This has relieved any stresses of isolation that many studies have cited for new faculty (see for example, Boice, 2000; Boice, 1990; Whicker et. al, 1993). I feel I can ask the questions I need to, without too much thought on how it will reflect on me or my work... One needs to feel safe in order to take such risks in unveiling what one does not know... It begs the question, what are we so afraid of in academia?(Letter to mentor, August 22, 2005).

Immediately after I was hired on faculty, Ruth McQuirter Scott and I began a professional mentor relationship. Having been the chair of my search committee, Dr. McQuirter Scott knew my passion for reflective writing and offered to begin writing with me on my journey as a new faculty member. It was (and still is) through our written letters that I was able to reflect deeply on the experiences of induction. Our written letters have now become a project we continue and as it relates to the larger Mentorship Program Dr. Scott leads in the Pre-service department.

What was discovered through our mentorship was that there needed to be a safe place for a 
community that allowed for risk to ask questions by new members as well as the need for veteran members to validate and acknowledge the needs of both new and existing faculty. I anxiously cited titles I was reading early on to Ruth, such as: "From Dissertation to Book" (Germano, 2005); "Advice for New Faculty Members" (Boice, 2000); "Getting Tenure" (Whicker et. al, 1993); "Professors as Writers" (Boice, 1990); "Successful Publishing in Scholarly Journals" (Thyer, 1994). Immediately, my anxiety was lessened with the mentorship Dr. Scott provided through validation, affirmation and acknowledgement, not just through our conversations and writings, but also through the Mentorship Program at large. The ability to share information was provided through various in-services, workshops, professional development days - all in a safe environment that focused on community building of new members with veteran faculty. Safe places were created where it was okay to admit, "I don't know what I'm doing! What do you think?" From my perspective, this essentially was what defined the learning faculty and how our new Dean of Education, James Heap, described scholarship,

\footnotetext{
"Whether carried out by senior professors, newly hired assistant professors, graduate or undergraduate students, or by staff, scholarship is learning" (Heap, 2005).
}

The focus on learning, for everyone, allowed for community to be created and sustained through new and veteran faculty. This allowed me to re-evaluate my anxiety and stress as a new faculty hire, to "see with new eyes", and to put perspective on my position in the learning faculty landscape.

\section{b) Understanding ourselves as learners and educators through critical incidences}

I re-read my letter to you, written in early January. I was as high as a kite, feeling so good about my accomplishments, family, my father, etc. As I reflect, I am so happy and content that I felt a sense of peace and tranquility about my life and family before my father's death. It has helped me to accept the circle of life and to let him go. I still have troubled sleep nights, dreaming of him dying, saying good-bye to us, looking lovingly at my mother... These memories are a still frame in my mind. Other memories are joyful, playful, especially of the sacred times over the last few years with my father and my children...these memories sting too. All the while, work at Brock has continued with full speed. In a sense, my busy work has saved me. I am distracted, occupied, always working at one thing or another... This is where the anxiety has its roots and I am thinking that, with my father's death and all else, the anxiety has surfaced into a numbness, a kind of "deer in the headlights" feeling, a vulnerability that I am not used to in my way of living. It's excruciatingly frustrating. (Letter to mentor, March 21, 2006)

There is no question that my induction year was filled with heart-felt emotion. How could it not have been, with the death of my father, and with the death of a student? What I want to suggest, and what has been brought to the forefront for me in my written reflections and readings, is that deep, even sorrowful, emotion has its roots in learning about ourselves as educators. Neumann (2006) recently makes a case that scholarly work is emotional in content and draws on our (as scholars) emotional resources. Critical incidences, such as death in my story here, cannot help but to awaken the human spirit in a manner that affects all areas of life - including work. The death of my father shook me deeply. I could not but react "in community" with others; this was my intrinsic way of being and living. My personal and professional life became one. So, as members of my professional community attended the funeral home and funeral, and as students reached out to me with their own stories of grief and sorrow, so too was I re-awakened into what my purpose was as a learner and scholar. The ultimate question that echoed for me, in all my anxiety, was: what message do I need to impart to others before I leave this earth too? This "passion to profess" or what Neumann (2006) refers to as professing passion, is what I believe is at the intersection of intellectual cognitive work and the emotion that sustains such work. I have discovered this anew, through another bittersweet story of death, in my induction year. I write to Ruth,

At the funeral... the minister read from Caitlin's final paper in my course. It did not chill but instead warmed me to the bones - like I had made a difference in not just one life, but several. Well, I hadn't made the difference, Caitlin had - I was merely the facilitator that allowed for it to happen through the "course" of my work. Course of my work funny, how I think of that phrase... "course of our work"... should really, in the most Deweyian sense mean 
the "course of our life". When will it end? And is the end the difference or the course - the in between...it's so profound, all these matters I am trying to grapple with at this time...This year has been powerful for me indeed, not just in the tragedy of death but in the meaning of what it means to live one's course of life. My induction year has had a most powerful impact on me, my family... and it has been a year I will treasure for the significant experiences I have had in it. And always I ask myself: but how will this matter to others? (Letter to mentor, June 20, 2006)

\section{c) Writing and teaching:} What brings us back to Joy?

Is it just me... or have we all felt the winds of change happening for our "learning faculty". What I mean is, does a veteran faculty feel as renewed as new faculty, do you suppose? I have felt so supported, not just by people like you, but also by 'the system' at Brock. [The CTL] presentations, for example, have been inspiring and so useful to "set us up for success". Your Mentorship Program has enabled further inspiration not just by new faculty but also by long standing faculty too. ... How can I not be inspired? How can I not glow with anticipated fulfillment? ...The question is, what is it in me now-i.e. these days with this new job - that has changed an outlook of life in me? Of course, I must take heed that this feeling of "high" cannot always last. But can a feeling of being satisfied with what one does last? Has it lasted for you in your career at Brock, or have there been stumbles along the way? What brings us back to A - to Joy? (Letter to mentor, January 1, 2006)

What brings us back to Joy? Through the anxiety and stresses of induction, through the pain and sting of grief, through the confusion and frustration of newness, what is it that grounds us as professors? For me, in my first year, it certainly has been my immediate family who unconditionally has supported my new career transition. But, in my career, in my work, the very thing that has sustained me and has given me a "flow" and "high" of fulfillment, throughout the stress, has been my students. In my writing and teaching, my students bring me back to $\mathrm{A}$, to Joy.

I only can say what I am about to through lived intuition, and I indeed may study it one day, but there is a tacit notion of teaching as fulfillment which sustains the faculty and staff in the Pre-service department at Brock University. This is what I have encountered, as affective notions of receiving, responding, valuing, relating and internalizing our moral values in community with various members in the learning faculty. To "become" a learning faculty in community this year meant that we needed to re-look, re-vision, and re-define what we do as educators as evidenced primarily in what and how we teach and in how we "run our course" of curriculum (or life) with our students. This is a process I am still a part of and continue to look forward to. My students, in my induction year, fulfilled the reason I was chosen as a member of the faculty of education in the first place. I evidenced this not through the positive course evaluations obtained but by the educational relationships that formed. When you intuitively know that, on most days, you have made a difference to a stu- dent's life, what else is there but to continue in the fulfillment and purpose of educating, of living your "course"?

\section{d) The ethics of care: What does it mean to care?}

I have a strong belief in... "revelations" which can happen in other teaching and professional places - like at Brock University. I hope to explore this avenue with you further through our letters and in conjunction with...our "Learning Faculty". Learning can and should always be reciprocal... Perhaps that is why I place further meaning to the word 'mentorship'. Never have I been in a mentorship role myself where I did not learn alongside my colleague or peer (in fact, sometimes I was the one that learned more!). I liken this as it relates to associate and student teachers, as it relates to professors and relationships with students and as it relates, of course, to us as peers, learning from each other - all of us ...For me, it's not enough to talk about this at a surface level but to delve deeply into the issues that affect our teaching and learning...I ask myself: what is it about sharing one's story of learning and teaching that makes it so universal, mutual and sometimes, if we're lucky, so revolutionary to curriculum as we see and use it today? (Letter to mentor, October 3, 2005)

Noddings (1992) speaks of a reciprocal notion of caring. To care for someone means also that the cared-for person accepts being cared for by the caring. The result is a mutual relationship of trust, respect, integrity and openness. Throughout my induction year, "ethical" values were made apparent to me in my darkest hours indeed. Both faculty and students gathered in community with me when my father 
passed away. Likewise, we gathered together when we heard of Caitlin's death. To care means to be sympathetic to another, to see and imagine what another feels and sees. We also need leaders (in order to model for others) who care in communities of learning. Sergiovanni (2005) describes "value-added" leadership in times of need, and explores virtues such as hope, trust, faith, community and even love. Palmer (1998), too, teaches on the love for teaching and learning. But, to care and be cared for means to embrace all facets and values of yourself, and another to be authentic to our own philosophies of life, but to be open to understand another's in our professional communities. I write to a colleague,

One of the notions that I hold very dear to education and learning is that it is truly about relationship... I believe that professional learning communities are only authentic if there is an ethic of care... When that variable is missing....well, so is the professional learning community! (Letter to colleague, January 23, 2006)

I was "cared-for" during my induction year. This was felt through authentic relationships with faculty, students and staff in the stories that I shared with them and in those that were reciprocated. When my father died, I taught classes the week after. Knowing the full extent of how death had consumed me, my work and my very being, I took it upon myself to be authentic in my teaching and to educate my students on the notion and emotions of death and what that meant in education. I spoke of my emotions, of the funeral, of the death. I presented a slide show with music of my family with abundant pictures of my father, smiling, happy, "living" in still-life. And then we discussed death and education, what happens in classrooms when students experience death of parents, siblings, family, or friends? I showed resources, and I described other experiences as a classroom teacher. This was one of my most powerful lessons, unplanned in my original course outline, but most fitting in our "course of life" at the time.

\section{Lessons Learned}

Stress on the tenure-track will undoubtedly be a constant, it must be admitted! And, getting through, up and over my induction year was no small feat, to be sure. The lessons learned were not without pain, grief, struggle and much intense reflection. However, what I have learned is that, now more than ever before, relationships matter in education. They matter because, when all is said and done in our "course of life", we have only ourselves to look to for further support, learning and guidance. The story of my induction year has offered hope in what it means to live in community in a learning faculty, to understand ourselves better through the critical incidences we experience, to find fulfillment in whatever it is that brings us back to Joy, and to understand what it means to care and be cared-for in the course of our lives.

My hope is that this story will remind educators of the vital and critical importance of building and sustaining mentorship as well as a culture of support and care in their learning communities. There are various resources to access.

- The Ontario College of Teachers at www.oct.ca/standards offers the revised standards and fosters professional inquiry kits (i.e. facilitator's handbook, inquiry practices and discussions through case/ story scripts)

- The Ontario Ministry of Education at www.edu.gov.on.ca/ eng/teacher/induction/html has announced its New Teacher Induction Program (NTIP) which fosters effective induction processes such as mentoring in support of school communities across Ontario

- Other websites on

mentorship that I have found helpful, include:

www.wisets.ualberta.ca/

mentorship.cfm and

www.sonic.net/ $\sim$ mfreeman/ mentor.htm

- Books on ethic of care and building inclusive leadership in learning communities:

"Inclusive Leadership" by James Ryan. 2006. Jossey-Bass Publishing.

ISBN 0787965081;

"Happiness and Education" by Nel Noddings. 2003. Cambridge University Press. ISBN 0521807638

\section{References}

Boice, R. (2000). Advice for new faculty members. Allyn \& Bacon, Needham Heights, MA.

Boice, R. (1990). Professors as writers: A self-help guide to productive writing. New Forum Press. Stillwater, Okla.

Clandinin, D. J., \& Connelly, F. M. (2000). Narrative inquiry: Experience and story in qualitative research. San Francisco. Jossey-Bass Publishers.

Connelly, F. M., \& Clandinin, D. J. (Eds.). (1999). Shaping a professional identity: Stories of educational practice. 
New York: Teachers College Press.

Connelly, F. M., \& Clandinin, D. J. (1987). Narrative inquiry: Storied experience. In E. Short (Ed.), Forms of curriculum inquiry (pp. 121 - 152). New York: State University of New York Press.

Germano, W. (2005). From dissertation to book. University of Chicago Press. Chicago.

Heap, J. (2005). Faculty Board document handout. September 21, 2005. Brock University.

Krathwohl, D.R., Bloom, B.S., and Masia, B.B. (1964). Taxonomy of educational objectives: Handbook II: Affective domain. New York: David McKay Co.

Neumann, A. (2006). Professing passion: Emotion in the scholarship of professors at research universities. American educational research journal. Vol. 43, no.3, pp. 381-424.

Noddings, N. (1992). The challenge to care in schools: An alternative approach to education. New York: Teachers College Press.

Palmer, P. (1998). The courage to teach: Exploring the inner landscape of a teacher's life. San Francisco: JosseyBass.

Sergiovanni, T.J. (2005). Strengthening the heartbeat: Leading and learning together in schools. San Francisco: Jossey-Bass.

Tjuer, B.A. (1994). Successful publishing in scholarly journals. Thousand Oaks, California.

Whicker, M.L., Kronenfeld, J.J., Strickland, R.A. (1993). Getting tenure. Sage Publications, Thousand Oaks, California

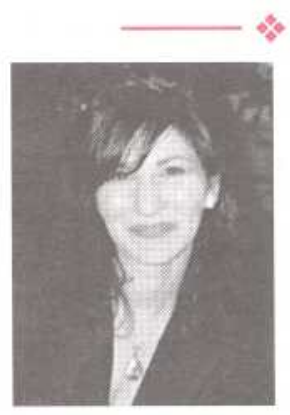

Darlene Ciuffetelli Parker has her $\mathrm{PhD}$ in Education and Curriculum and is a professor at Brock University. She has had extensive experience as a former teacher, literacy consultant and school administrator. Her research and writing stems from adults' and students' personal narratives of what it means to be literate and how multiple languages affect our place in society, school and family.

\section{Managing Stress through Music Intervention: An Interview with}

\section{Adrienne Pringle}

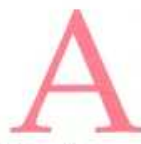
drienne Pringle is an ac complished vocalist and instrumentalist. She is a highly qualified Music Therapist who provides care and support to palliative care patients at Credit Valley Hospital, Mississauga, Ontario, Canada, but has also taugh music therapy courses, and supervises students at Wilfrid Laurier University, works in schools and with individuals at home and private practice. I have had the privilege to observe and witness first hand her efforts on behalf of patients and co workers. Her impact is nothing short of outstanding and serves as a reminder of the power of the gift that care givers provide to those who are in need spans across all professions. Her insight about how music therapy can be helpful in alleviating stress reveals much about this very special professional skill.

Chodzinski: Please describe for our readers the qualifications and roles of a music therapist.

Pringle: A music therapist is an accomplished musician who has received specialized training in music, psychology and the clinical use of music in therapy. The music therapist has graduated from an honours bachelor of music therapy program or a master's degree in music therapy at an accredited university. Upon completion of the four-year music therapy degree, the music therapist must then complete a one thousand hour internship under the supervision of an accredited music therapist. After the internship is completed, the music therapy intern submits a file of specific documentation to the $\mathrm{Ca}$ nadian Association of Music Therapy (CAMT) to be reviewed by the accreditation board. If the accreditation file meets the standards of the CAMT, the music therapist is granted the status of music therapist accredited (MTA). The field of music therapy is regulated both federally by the Canadian Association of Music Therapy (CAMT), and provincially (in Ontario) by the Music Therapy Association of Ontario (MTAO). As a musician, the music therapist uses musical elements such as harmony, melody, rhythm, and form as tools to meet the goals that are predetermined for the client. As a therapist, the music therapist recognizes the ability of music to affect behaviour, and adjusts the musical experiences of singing, moving, playing instruments, improvising, composing and listening in order for the client to receive the maximum benefit from the session.

Chodzinski: This issue is about stress in school communities. Please explain for our readers what music therapy is and how music therapists such as your self might assist to teachers and administrators, students and parents in schools.

Pringle: Pringle: Music therapy is the skillful use of music and musical elements by an accredited music 